Piotr Cichociński

ORCID: 0000-0002-8633-1235

\title{
A STUDY ON THE USABILITY OF OPEN SPATIAL DATA FOR ROAD NETWORK-BASED ANALYSIS - USING OPENSTREETMAP AS AN EXAMPLE
}

\author{
AGH University of Science and Technology, Kraków, Poland
}

Keywords: data quality, quality categories, standardization, network analysis, feature length

\begin{abstract}
For several years GIS software users could use for any purpose a dataset being to some extent an alternative to both products offered by commercial providers and official databases. It is OpenStreetMap (OSM for short) - a worldwide spatial dataset, created and edited by interested individuals and available for use by anyone with no limitations. It is built on the basis of data recorded with consumer grade GPS receivers, obtained through vectorization of aerial photographs and from other usable sources, including even sketches made in the field. The collected information is stored in a central database, the content of which is not only presented on the website as a digital map, but also offered for download as vector data. Such data can be used for, among other things, performing various analyses based on road networks, of which the most frequently used is the function of determining the optimal route connecting selected locations.

The results of such analyses can only be considered reliable if the data used are of adequate quality. As the OSM database is built by enthusiasts, no plans for its systematic development are formulated and there are no built-in quality control mechanisms. Therefore, the paper proposes methods and tools to verify the usefulness of the data collected so far, as well as to correct detected errors. It focuses on the following categories of geographic data quality: location accuracy, topological consistency and temporal validity.

In addition, a problem with determining the length of individual road network segments was noticed, related to data acquisition methods and ways of recording the shape of lines. Therefore, in order to carry out the so-called route calibration, it was suggested to use kilometer and hectometer posts used in transportation networks, the locations of which are successively added to the OSM database.
\end{abstract}

\section{BADANIE UŻYTECZNOŚCI OTWARTYCH DANYCH PRZESTRZENNYCH DO ANALIZ OPARTYCH NA SIECIACH DROGOWYCH - NA PRZYKLADZIE OPENSTREETMAP}

Słowa kluczowe: jakość danych, kategorie jakości, normalizacja, analizy sieciowe, długość obiektu

\begin{abstract}
Abstrakt
Od kilkunastu już lat użytkownicy oprogramowania GIS mogą używać do dowolnych celów zbioru danych będącego do pewnego stopnia alternatywą zarówno dla produktów oferowanych przez dostawców komercyjnych, jak i urzędowych baz danych. Jest nim OpenStreetMap (w skrócie OSM) - obejmujący cały świat zbiór danych przestrzennych, tworzony i edytowany przez zainteresowane osoby i dostępny do stosowania przez każdego chętnego bez żadnych ograniczeń. Budowany jest na podstawie danych rejestrowanych turystycznymi odbiornikami GPS, pozyskiwanych poprzez wektoryzację zdjęć lotniczych oraz pochodzących z innych nadających się do wykorzystania źródeł, w tym nawet szkiców wykonywanych w terenie. Zgromadzona
\end{abstract}


informacja zapisywana jest w centralnej bazie danych, której zawartość jest nie tylko prezentowana na stronie internetowej w postaci cyfrowej mapy, lecz również oferowana do pobrania jako dane wektorowe. Takie dane mogą mieć zastosowanie między innymi do przeprowadzania różnorodnych analiz bazujących na sieciach drogowych, z których najczęściej wykorzystywana jest funkcja wyznaczania optymalnej trasy łączącej wybrane lokalizacje.

Wyniki takich analiz można uznać za wiarygodne tylko wtedy, gdy użyte w nich dane będą się charakteryzować odpowiednią jakością. Ponieważ baza danych OSM budowana jest przez pasjonatów, nie są formułowane żadne plany jej systematycznego rozwoju oraz brak jest wbudowanych mechanizmów kontroli jakości. Dlatego w artykule zaproponowano metody i narzędzia, które pozwolą na weryfikację przydatności zgromadzonych do tej pory danych, jak również na poprawę wykrytych błędów. Skupiono się na następujących kategoriach jakości danych geograficznych: dokładności położenia, spójności topologicznej oraz ważności czasowej.

Dodatkowo dostrzeżono problem z wyznaczaniem długości poszczególnych obiektów sieci drogowej, związany z metodami pozyskiwania danych i sposobami rejestracji kształtu linii. W związku z tym do przeprowadzenia tak zwanej kalibracji trasy zasugerowano użycie stosowanych w sieciach transportowych słupków kilometrowych i hektometrowych, których lokalizacje są sukcesywnie wprowadzane do bazy danych OSM.

\section{INTRODUCTION}

A network is defined as a system of interconnected linear objects through which resources are transmitted or based on which traffic takes place (Husdal, 1999). A network data model is an abstract representation of the components and characteristics of real network systems. It can be described as a graph, which consists of edges representing linear flow channels and nodes representing the connection points between the edges. In the case of a road network, edges represent the centerlines of roads and streets, and nodes correspond to intersections. In order for the network to act as a real world model, additional information associated with the edges is needed. It specifies the allowable directions of movement and some value that represents the cost (or resistance) of movement along particular sections of the network. The easiest to determine is the length of the edge.

Based on this type of data, network analysis functions in geographic information systems (GIS) software operate to examine the possibilities of movement along individual network components. The most widely used and common is the function of determining the optimal route between two or more points.

Performing network analysis requires the collection and preparation of data. The leader in this field is Google Inc. (Obeirne, 2017), which manages a spatial database covering almost the entire world and provides services based on it, including routing. And while such services can be considered free for individuals, their use in a business environment is associated with fees. Additionally, these fees were significantly increased in 2018 (Owczarek, Nawrocki, 2018). Users also do not have access to the data and thus cannot conduct analyses based on it using their own software.

Therefore, an interesting alternative may be OpenStreetMap (Haklay, Weber, 2008) - a community project aiming at creating an editable and freely available map of the world. Such map is created on the basis of data from consumer grade GPS receivers, aerial photographs and other formally and legally usable data sources, as well as sketches made in the field. The main difference from Google Maps is that users have access not only to the map image displayed on the website, but they can also download vector data stored in the database. Due to the way of creating such a set, data from this source needs to be verified before each use, errors need to be corrected and gaps need to be filled.

\section{CHARACTERISTICS OF OPENSTREETMAP}

The project was created because most maps that are commonly thought to be free actually have legal or technical restrictions on their use. OpenStreetMap resources are made available under the Open Database License (OdbL) (Open Knowledge Foundation, 2021), which allows a database to be used for any purpose, including creation of derivative works, provided it is attributed in a manner specified by the creator or licensor and the newly created work is distributed under the same license.

The condition for data to be added to the OpenStreetMap (OSM) database is that it is correct, verifiable and not covered by copyright or that the person entering the data has full rights to it. Data is stored in OSM database in the form of labeled geometric primitives. They be- 
long to one of three types: points (node), lines (way) and relations. Areas are represented by closed lines (the first point is identical to the last). More complex structures (for example, areas with enclaves) are constructed using relations. Each of these types can have tags attached to them, which take the form of key-value pairs and act as attributes. There is a precise list of accepted keys and values (OpenStreetMap, 2021), which can be expanded by a vote of community members, but although not recommended, it is acceptable to use keys and values from the outside of this list.

As this database is built by volunteers, no plans for its systematic development have been formulated. Adding new data depends on the willingness of individuals to make appropriate field measurements or vectorize available aerial photographs. However, there are cases when companies or institutions holding various data in their resources decide to donate them free of charge to the OpenStreetMap community. On a global scale, the permissions granted by Yahoo and Microsoft for unlimited use of data (in particular aerial photographs) presented on their map portals are significant. In Poland, an amendment to the Geodetic and Cartographic Law effective from 31 July 2020 (Act, 2020) resulted in the opening of many spatial datasets (including the database of topographic objects) that are part of the State Geodetic and Cartographic Resources and thus gave the possibility to use them for the creation of OSM.

\section{GEOGRAPHIC INFORMATION QUALITY}

The standard (ISO 9000, 2015), dedicated to the fundamentals of quality management systems, defines quality as the totality of characteristics of a product that depends on its ability to satisfy expressed and implicit needs. In a nutshell, it can be said that quality indicates suitability for use. In the field of geomatics, quality description has two main objectives:

- to allow a producer of geographic data to evaluate how well a dataset meets the criteria set forth in its product specification,

- to assist data users in evaluating a product's ability to satisfy the requirements for their particular application.

Spatial data quality should be considered from four aspects (ISO 19157, 2013):
- purpose - the rationale for creating a dataset and information about its intended use, which may not be the same as the actual use of the dataset,

- usage - the applications for which a dataset has been used, either by the data producer or by other data users,

- lineage - the history of a dataset and the life cycle of a dataset from collection and acquisition through compilation and derivation to its current form,

- quantitative measurement against a quality benchmark - such a benchmark is called a nominal ground or universe of discourse, and is a model representing a particular view of the real world an ideal geographic dataset.

A data quality evaluation procedure comprises one or more data quality evaluation methods. These can be divided into two main classes: direct and indirect. Indirect evaluation methods infer or estimate data quality using information on the data such as usage, lineage or purpose. Therefore, direct evaluation methods should be used in preference to indirect evaluations.

A direct evaluation method is a method of evaluating the quality of a dataset based on inspection of the items within the dataset. The direct evaluation methods can be classified as internal or external. Internal direct data quality evaluation uses only data that resides in the dataset being evaluated (an example would be the assessment of topological consistency). External direct quality evaluation requires reference data external to the dataset being tested (examples include: assessing completeness or assessing accuracy of location).

For both external and internal evaluation methods, one of the following inspection methods may be used: full inspection or sampling. Full inspection tests every item in the population specified by the data quality scope. Sampling means that tests are performed on subsets of the geographic data defined by the data quality scope. In the latter case, it is important to correctly determine the sample size, which is more difficult for geographic data than for tabular data. Sample size may be related to the number of features of a given type, the area covered by the dataset, the total length of curves in the dataset, the total number of vertices describing curves or areas in the dataset.

Degree of compliance with the benchmark (universe of discourse) is indicated by the following five quality categories: 
1. Completeness - the presence and absence of features, their attributes, and relationships.

2. Logical consistency - the degree of adherence to logical rules of data structure, attribution, and relationships (data structure can be conceptual, logical or physical).

3. Positional accuracy - the accuracy of the position of features within a spatial reference system.

4. Thematic accuracy - accuracy of quantitative attributes and the correctness of non-quantitative attributes and of the classifications of features and their relationships.

5. Temporal quality - quality of the temporal attributes and temporal relationships of features.

\section{LENGTH OF GEOGRAPHIC FEATURES}

An issue that is not considered in the (ISO 19157, 2013) standard is the accuracy of determining the length of features. OpenStreetMap contributors mainly use three technical approaches to the development of accurate centerline geometry:

- to a limited extent, centerlines are derived from aerial photographs (or orthophoto maps),

- GPS tracks from multiple vehicles are resolved into centerlines,

- data are integrated from municipalities, utilities and other sources.

Tests of consumer grade GPS units showed that the accuracy of such devices is sufficient for this purpose. For instance Noronha and Church (2002) recorded centerline data while driving with a receiver suspended from a rear-view mirror of a car. Even on winding mountain roads they obtained deviations not exceeding $0.5 \%$ in relation to lengths measured with more precise instruments.

In contrast to the GPS measurement, digitization of a centerlines from aerial photographs or older maps inevitably introduces error and generalization, the amount of which depends on the source scale. It is generally well known that as a polyline is subjected to increasing generalization, the digitized length decreases. Due to measurement error, a location just short of an intersection may be erroneously recorded for instance as falling beyond the intersection. This is potentially a serious error; the likelihood and severity are entirely context dependent and difficult to quantify.

Research conducted by Noronha and Goodchild (2000) revealed that datasets from Santa Barbara region in the United States showed average differences of $8 \%$ in digitized length (longest versus shortest version of the same road) on a variety of roads, with a range of $1-16 \%$. The deviation of digitized length from length determined by Distance Measuring Instrument (DMI) for a given dataset over all sample roads ranged from $0.5 \%$ to $4 \%$ with an average of $3 \%$.

\section{CHOSEN PREVIOUS OPENSTREETMAP QUALITY RESEARCH}

The most comprehensive assessment of OpenStreetMap accuracy was presented by Girres and Touya (2010) and focused on the area of France. A wide range of quality elements were analyzed, such as geometric, attribute, semantic and temporal accuracy, logical consistency, completeness, lineage and usage. Much of the work done involved comparison with official data from the French Institut Géographique National (IGN).

As stated by the authors of the above study, it was an extension of work previously presented in a paper (Haklay, 2010), focused on comparing the accuracy of OSM with UK Ordnance Survey (OS) maps. Haklay assumed, given the quality assurance procedures in place, that the Ordnance Survey datasets had higher accuracy (at least in terms of location and attributes). There was also a formal requirement for $99.6 \%$ of significant real world features to be presented in the database within 6 months of their creation.

However, not always other datasets against which one would like to make a comparison can be considered more accurate. This is shown, among others, by the results of the research described in (Ciepłuch et al., 2010) and (Zielstra, Zipf, 2010). The first of these papers presents the results of a manual comparison of OSM accuracy with popular commercial products: Google Maps and Microsoft Bing Maps for the area of Ireland. A capital city, a small and large city and a university town were selected for analysis. Completeness, validity, and accuracy against reality were examined based on field verification of the data. It turned out that none of the three databases examined was of consistent quality and 
there were obvious errors in each of them. However, Zielstra and Zipf conclude that, at least in the areas of large German cities, OpenStreetMap can be an interesting alternative to, as they put it, "professional" datasets.

Therefore, studies and proposed methods that do not require reference data should be considered extremely valuable. In particular, Barrington-Leigh and Millard-Ball (2019) fitted a sigmoid curve to a graph showing the cumulative length of features entered into the OpenStreetMap database and used it to estimate saturation levels for individual countries. On this basis, they found that globally, OSM is about $83 \%$ complete, and more than $40 \%$ of countries, including developing ones, have a fully mapped road network.

In turn, Nasiri et al. (2018) presented a novel approach for improving the positional accuracy and completeness of the OSM road network. Through applying the Voronoi diagram method, they extracted one representative version from multiple mappings of the same road, which can be compared to the determination of the average from multiple measurements, which has a higher accuracy than a single measurement. Given a case study in Tehran, their findings revealed that the completeness and positional precision of OSM features could be improved up to $14 \%$.

\section{ANALYSIS OF SELECTED OPENSTREETMAP DATA QUALITY CATEGORIES}

\subsection{Logical (topological) consistency}

An important limitation in using different datasets for network analysis is the spatial relationships between lines - when the end of one line does not precisely meet the ends of other lines in the dataset. Also, when lines intersect, it needs to be determined whether this is intentional or should be treated as an error. Often GIS software "fixes" any line intersections by dividing them into smaller parts, with their ends touching each other. The result is a planar graph. However, there are situations where this is undesirable, for example when modeling multi-level intersections (Fischer, 2003). Therefore, each such case should be considered individually. Instances of minor inaccuracies in the linkage of lines, resulting, for example, from rounding of coordinates, can be automatically corrected on the assumption that if two ends of a line are no more than a certain toler- ance away from each other, they should be considered identical and certainly form a single node.

While other qualitative elements require in practice a labor-intensive comparison with the actual course of roads and streets, geometric consistency can be examined by internal evaluation methods. Topology used to describe spatial relationships between geographic features can help to solve this problem (Cichociński, 2007). In the case of such sets of features as the road network, in order to check geometric consistency it is sufficient to use two topological rules: "lines must not intersect and overlap", "lines must touch each other only with their ends". Once errors detected in this way are flagged, they can be corrected either by automatic methods (in the case of intersections), or by semi-automatic or manual methods (in the case of dangling node errors).

Another practical solution is to use the spatialite osm_net software, which is one of the tools accompanying the SpatiaLite spatial database management system (Krawczyk, 2012). It processes an XML file containing OpenStreetMap data and stores in the spatial database table selected features with the highway tag, which are elements of the road network on which vehicle traffic is allowed. Moreover, an attribute describing the cost of traffic along particular network segments is added, calculated on the basis of arbitrarily assumed maximum speeds for particular road types (motorway, primary, secondary, etc.). However, the most important effect of the program operation is the correction of the vast majority of topological errors occurring in the data, while preserving such critical places as multi-level intersections. It is also important to convert polygons such as roundabouts into lines representing their perimeters, as only in this form they can be used in network analyses.

\subsection{Positional accuracy}

In the case of point features, the distance between the surveyed and reference locations can be easily and unambiguously determined. For linear objects the task is not so simple to perform. In the literature one can find various proposals for determining differences in the location of such objects. The more popular measures include the Hausdorff distance (Hanguet, 1995) and the part of the total length of a lower accuracy feature that is at a certain distance from a higher accuracy feature (Goodchild, Hunter, 1997) (Hunter, 1999). 


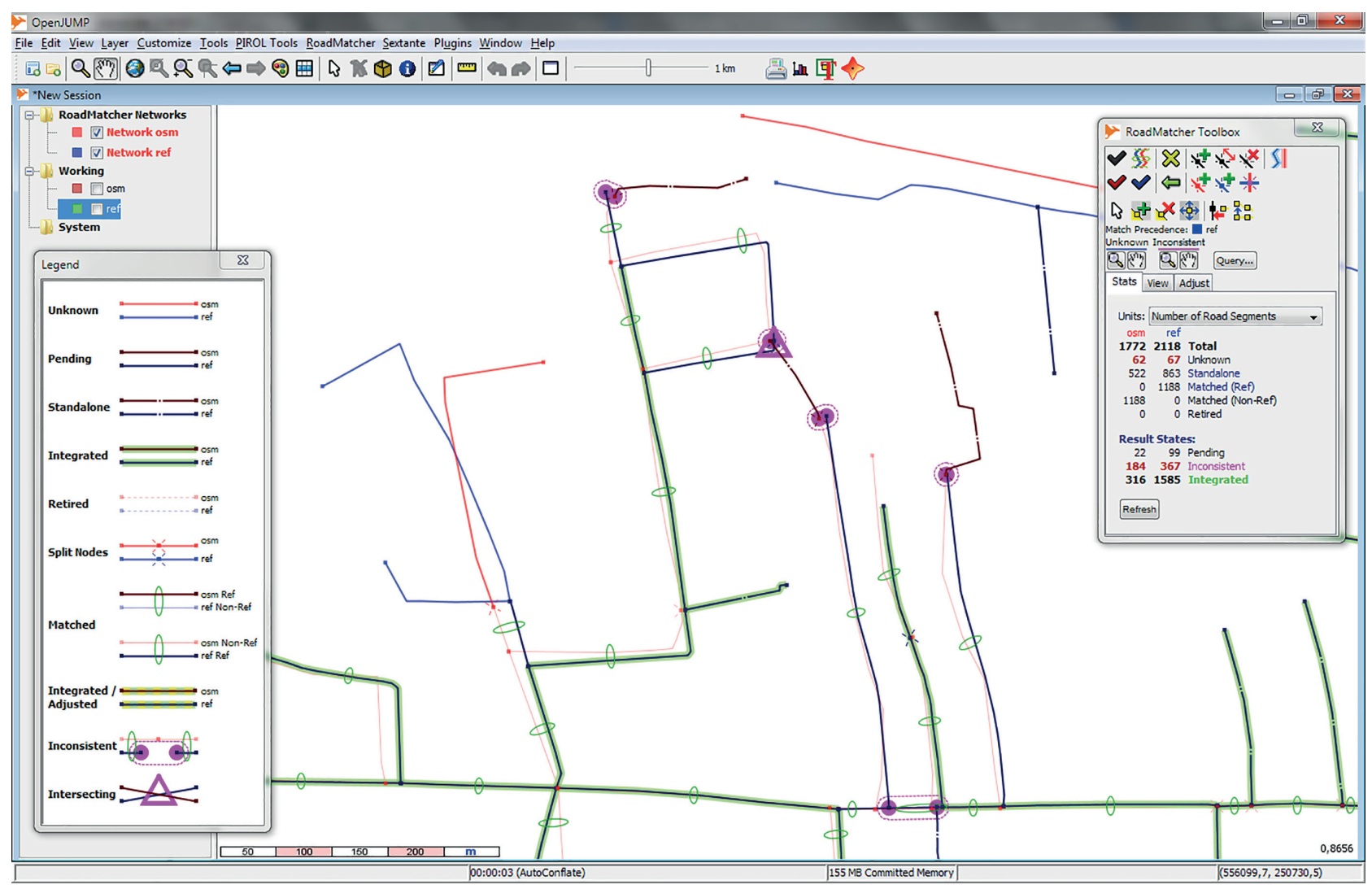

Fig. 1. The result of road matching - corresponding elements from two datasets are symbolically linked by green ellipses. Source: Author's own work

Rys. 1. Wynik działania programu RoadMatcher - odpowiadające sobie elementy z dwóch zbiorów danych są symbolicznie powiązane za pomocą zielonych elips. Źródło: opracowanie własne

A tool is available that, using the methods described above, will allow, although this is not its main purpose, to evaluate the accuracy of the position of linear feature. This tool is the RoadMatcher software (Vivid Solutions, 2005). The main task of this software is to find matching elements in two network datasets (fig. 1) and then combine them to create one coherent resulting dataset. To ensure a one-to-one match in some cases it is necessary to split the elements into shorter segments. One of the matched elements, identified as preferred, becomes the reference element and is included in the resulting network. If there is no match, the element may be directly transferred to the resulting dataset, or it may be discarded.

The RoadMatcher software was used to evaluate the accuracy of road locations in the area of the Zabierzów commune near Kraków. The Author has at his disposal information on the course of the road network in this area, obtained by vectorizing road centerlines from base and cadastral maps. For the same area, data in XML format was downloaded from http://openstreetmap.org and converted to the shapefile format using spatialite osm net software.

Corresponding network elements were identified in RoadMatcher within a user-defined search radius. This was started with a default value of $10 \mathrm{~m}$. As not all pairs were created, and distances between features as large as several tens of meters were observed, the search radius was eventually set to $60 \mathrm{~m}$. The original number of 1341 elements in the OSM dataset and 1891 in the reference dataset increased to 1772 and 2118 , respectively, due to the necessity of a better matching division into shorter segments. The search radius included 1188 features of similar shape in each dataset, as well as 62 features in the OSM dataset and 67 in the reference dataset that differed significantly in shape. 522 and 863 features, respectively, were found to be completely different and without counterparts in the other dataset. 
For 1188 pairs of related features, the Hausdorff distance could be calculated. The minimum distance determined was $0.04 \mathrm{~m}$, the maximum $41.81 \mathrm{~m}$, the mean $4.47 \mathrm{~m}$ and the standard deviation of the mean $4.34 \mathrm{~m}$. This confirmed the finding of Haklay (2010) who noted that on average the deviation from Ordnance Survey data did not exceed $6 \mathrm{~m}$. Therefore, the $6 \mathrm{~m}$ distance was used to determine nearness, which was the percentage of the total length of an OSM feature contained within a buffer zone of a specified size around the reference feature. The average nearness value reached $91 \%$.

\subsection{Temporal quality}

An important and specific characteristic of OpenStreetMap is its instant reaction to the emergence of new road network elements. This is especially true for important roads such as motorways. A newly opened section is almost immediately visible on the map. This is made possible, among other things, by the fact that the database also stores information about roads under construction and planned. It is therefore only necessary to change the value of the highway tag from construction to the correct one, describing the class of the road already in operation.

\subsection{Accuracy of length measurements}

One of the advantages of OSM is that, in contrast to most commercial digital street networks and also popular services such as Google Maps, it records kilometer post designations. They are represented by nodes with the appropriate tagging:

- highway=milestone (tag denoting kilometer post),

- distance tag denoting distance from beginning of the road (for instance distance $=238$ - value read from kilometer post),

- reftag denoting road number (for instance $r e f=22-$ value, like the one above, can be read from kilometer post).

Posts should be placed every $100 \mathrm{~m}$ along the edge of the road and marked with a number of kilometers (and hectometers) representing the distance of a given post from the beginning of the road. In Poland, the beginning and the end of the road are: state border, intersection with another public road, seaport border. The beginning of a road mileage is a reference point at the beginning of its course, which is given a mileage of $0[\mathrm{~km}]$. The mileage usually increases from north to south or from west to east (Order, 2012).

They can be used as control points in a calibration process defined as correcting two-dimensional lengths of road network segments based on three-dimensional measurements taken in the field and fixed as points with known distances measured along the road (Bigham, Kang, 2013). During calibration, the known measures associated with posts are assigned to the corresponding road locations based on comparison and matching of unique identifiers. On this basis the road segments between adjacent posts are then assigned actual lengths.

To test the usability of such a solution, LRS plug-in for QGIS software was used (Blazek, 2017). One of the outputs from this tool was a layer, which for each linear feature presented relative error, calculated as difference between a distance calculated from measures defined as point (posts) attributes and a length of the line between these points. The analysis of such errors showed, that for taken into account 188 distances between kilometer posts, maximum error was $292 \mathrm{~m}$ (29\%), while mean was $20 \mathrm{~m} \mathrm{(2 \% )} \mathrm{and} \mathrm{standard} \mathrm{devi-}$ ation was $39 \mathrm{~m} \mathrm{(4 \% ).} \mathrm{This} \mathrm{way} \mathrm{it} \mathrm{was} \mathrm{proven,} \mathrm{that} \mathrm{route}$ calibration significantly improved the accuracy of route length determination.

\section{CONCLUSIONS}

The examples presented above show that tools exist and are available to anyone interested in checking the correctness of OpenStreetMap data. With their help it is relatively easy to perform quality evaluation with internal methods that do not require possession of additional data. Quality evaluation methods using external data are also not overly complicated, but the possibility of their use is limited and dependent on access to other resources with higher accuracy. In addition, as the literature studies have shown, there is a danger that errors will be present in any potential reference dataset.

In spite of this, the results of the positional accuracy evaluation performed can be considered the most valuable. They show that despite small average differences occurring between corresponding feature representations in two compared datasets, there is a significant number of coarse errors, not resulting at all from source materials available to the contributors. On the other hand, the results of the line length calibration indi- 
cate that a few percent difference between the distances determined from the shape of the objects collected in the OSM database and those actually traveled in the field must be accounted for.

Acknowledgments: This work was prepared within the scope of the research funds from the AGH University of Science and Technology in Krakow, no. 16.16.150.545.

\section{REFERENCES}

Act of 16 April 2020 amending the act - Geodetic and Cartographic Law and certain other acts. Journal of Laws from 2020, item 782.

Barrington-Leigh C., Millard-Ball A. (2019): The world's user-generated road map is more than $80 \%$ complete. PLOS ONE 14(10): e0224742.

Bigham J., Kang S. (2013): Building a highway linear referencing system from preexisting reference marker measurements for transportation data management. In URISA (Vol. 25, No. 1).

Blazek R. (2017): LRS Plugin for QGIS. https://blazek.github. io/lrs/release/help.1.2.0/index.html

Cichociński P. (2007): Zastosowanie zaawansowanych reguł topologicznych w procesie budowania baz danych przestrzennych wspomagających wycenę nieruchomości (Application of advanced topological rules in the process of spatial databases creation to support real estate valuation). Roczniki Geomatyki (Annals of Geomatics), Vol. V, No. 3, pp. 29-25.

Ciepłuch B., Jacob R., Mooney P., Winstanley A. (2010): Comparison of the accuracy of OpenStreetMap for Ireland with Google Maps and Bing Maps. Proceedings of the Ninth International Symposium on Spatial Accuracy Assessment in Natural Resources and Environmental Sciences. Leicester, UK, 20-23 July 2010.

Fischer M.M. (2003): GIS and Network Analysis. ERSA conference papers. 43rd European Congress of the European Regional Science Association. Jyväskylä, Finland, $27^{\text {th }}-30$ th August 2003.

Girres J.-F., Touya G. (2010): Quality Assessment of the French OpenStreetMap Dataset. Transactions in GIS, 2010, 14(4): 435-459.

Goodchild M.F., Hunter G.J. (1997): A Simple Positional Accuracy Measure for Linear Features. International Journal of Geographical Information Science, 11(3): 299-306.

Haklay M., Weber P. (2008): OpenStreetMap: User-Generated Street Maps. IEEE Pervasive Computing, October-December 2008, pp. 12-18.

Haklay M. (2010): How good is volunteered geographical information? A comparative study of OpenStreetMap and Ord- nance Survey datasets. Environment and Planning B, 37(4) 682-703.

Hanguet J.F. (1995): Computation of the Hausdorff distance between plane vector polylines. Proceedings of AUTO-CARTO 12, 4; 1-10.

Hunter G.J. (1999): New tools for handling spatial data quality: moving from academic concepts to practical reality. URISA Journal, 11(2), 25-34.

Husdal J. (1999): Network analysis - network versus vector A comparison study. http://www.husdal.com/1999/10/11/ network-analysis-raster-versus-vector-a-comparison-study/

ISO 19157:2013 Geographic information — Data quality.

ISO 9000:2015 Quality management systems — Fundamentals and vocabulary.

Krawczyk A. (2012): Możliwości wykorzystania personalnej bazy danych przestrzennych SpatiaLite w praktyce górniczej (The possibility to use the SpatiaLite personal spatial database in mining practice). Roczniki Geomatyki (Annals of Geomatics), Vol. 10, No. 2, pp. 45-49.

Nasiri A., Ali Abbaspour R, Chehreghan A., Jokar Arsanjani J. (2018): Improving the quality of citizen contributed geodata through their historical contributions: The case of the road network in OpenStreetMap. ISPRS Int J Geo-Inf. 7(7): 253.

Noronha V., Church R.L. (2002): Linear Referencing and Alternate Expressions of Location for Transportation. California Department of Transportation.

Noronha V., Goodchild M.F. (2000): Map accuracy and location expression in transportation - reality and prospects. Transportation Research Part C: Emerging Technologies, 8(1): 53-69.

Obeirne J. (2017): Google Maps's Moat. How far ahead of Apple Maps is Google Maps? https://www.justinobeirne.com/ google-maps-moat

Open Knowledge Foundation (2021): Open Data Commons Open Database License (ODbL) v1.0. https://opendatacommons.org/licenses/odbl/

OpenStreetMap (2021): Map features. OpenStreetMap Wiki. https://wiki.openstreetmap.org/wiki/Map features

Order No. 18 of General Director for National Roads and Motorways of 1 July 2012 on rules for determining and conducting mileage of national roads.

Owczarek B., Nawrocki T. (2018): Pożegnanie z Google Maps (Farewell to Google Maps). https://www.gdziepolek.pl/blog/ pozegnanie-Z-google-maps

Vivid Solutions (2005): RoadMatcher. http://www.vividsolutions.com/products.asp?catg $=$ spaapp \&code=roadmatcher

Zielstra D., Zipf A. (2010): A Comparative Study of Proprietary Geodata and Volunteered Geographic Information for Germany. Proceedings of the 13th AGILE International Conference on Geographic Information Science. 10-14 May 2010, Guimarães, Portugal. 